\title{
Palm leaves from the Late Oligocene sediments of Makum Coalfield, Assam, India
}

\author{
Gaurav Srivastava $^{1, *}$, R C Mehrotra ${ }^{1}$ and Hugues Bauer ${ }^{2}$ \\ ${ }^{1}$ Birbal Sahni Institute of Palaeobotany, 53 University Road, Lucknow 226 007, India. \\ ${ }^{2}$ Bureau de Recherche Géologiques et Minières (BRGM) Regolith and Reservoir Geology Division, \\ 3 Avenue C. Guillemin, BP 36009, 45060 Orléanscedex 2, France. \\ *Corresponding author. e-mail: gaurav_jan10@yahoo.co.in
}

Two new palm leaf impressions, cf. Iguanura wallichiana and Palmacites makumensis sp. nov. are described from the Makum Coalfield, Tinsukia District, Assam. They belong to the Tikak Parbat Formation being considered as Late Oligocene (Chattian 28-23 Myr) in age. Their presence, along with the other known fossil records indicates that CMMT (cold month mean temperature) was not less than $18^{\circ} \mathrm{C}$ with plenty of rainfall, in the region during the period of deposition.

\section{Introduction}

Palms (Arecaceae) are a diverse group of plants confined to the tropical and subtropical regions of the world (Henderson et al 1995). The family comprises 183 genera with 2500 species (Govaerts and Dransfield 2005; Dransfield et al 2005, 2008). Palm species richness is highest in tropical Asia (>1200 species) and the Americas (730 species), while only 65 species occur in Africa (Dransfield et al 2008). The family has been placed within the commelinid clade of the monocotyledons (Chase et al 2006; Davis et al 2006) and composed of five sub-families: Arecoideae, Calamoideae, Ceroxyloideae, Coryphoideae and Nypoideae (Dransfield et al 2005, 2008).

It is speculated that palms have been originated in Australasia (including New Caledonia, New Guinea and New Zealand) (Bremer and Janssen 2005) though the oldest definite megafossil record is from the Late Cretaceous (Turonian) of France (Dransfield et al 2008). A recent paper (Couvreur et al 2011) considers palms to be of Laurasian origin based on generic level phylogenetic study. Fossil records of palms are less known from the tropics in comparison to those from the middle latitudes (Harley and Morley 1995; Dransfield et al 2008). In this paper, we have described two new leaf impressions of palms from the Late Oligocene (Chattian 28-23 Ma) sediments of Makum Coalfield, Assam which was located at $10^{\circ}-15^{\circ} \mathrm{N}$ palaeolatitude during the period (Molnar and Stock 2009).

\section{Geological setting}

The Makum Coalfield is the most important coalfield of northeast India as far as the resources of coal and infrastructural facilities are concerned. This field accounts for nearly $90 \%$ of the production of coal in this part of the country and has very well developed mines. This field lies between the

Keywords. Arecaceae; Assam; India; Late Oligocene; Makum Coalfield; fossil palms; Tikak Parbat Formation; northeast India. 


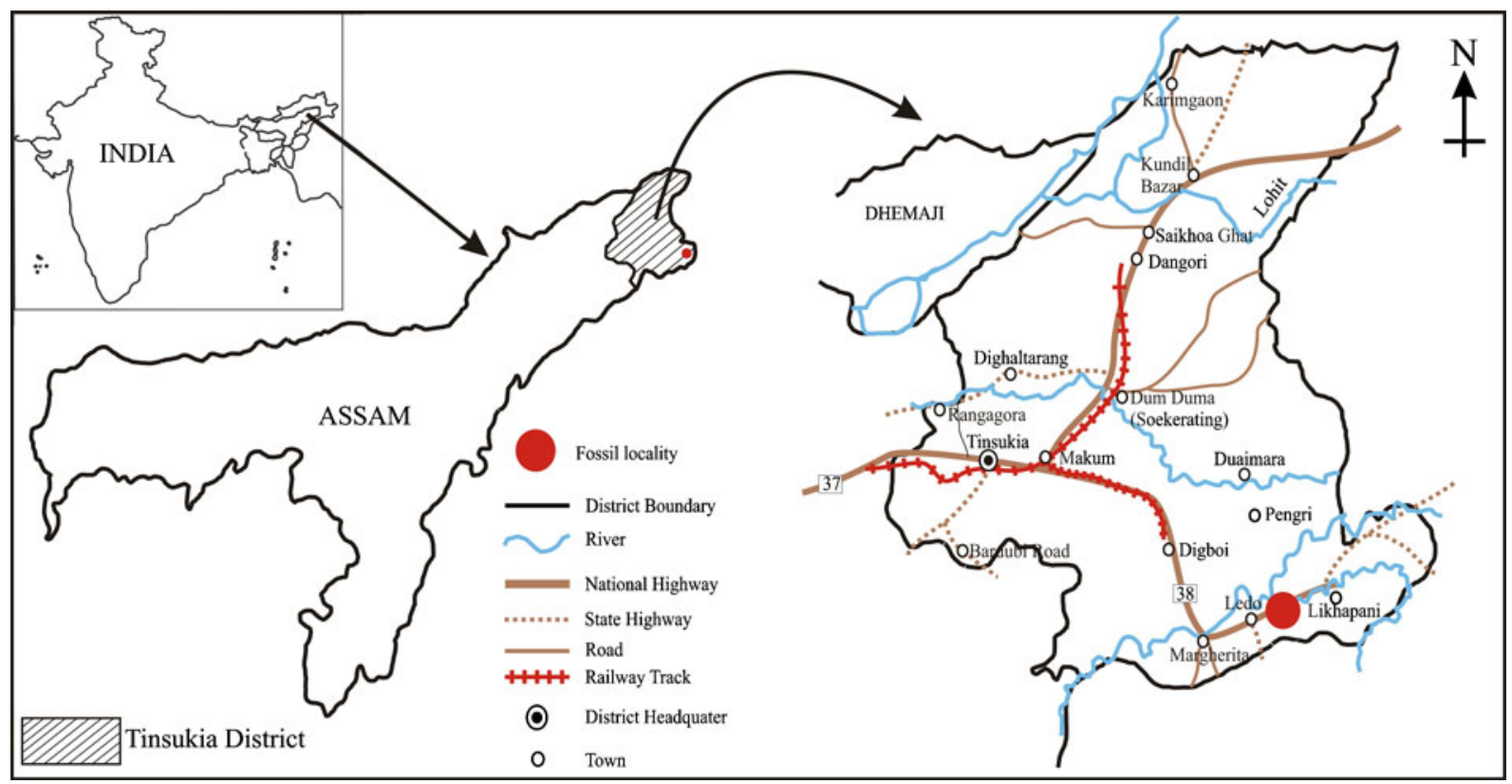

Figure 1. Map of Assam showing the fossil locality in Tinsukia District.

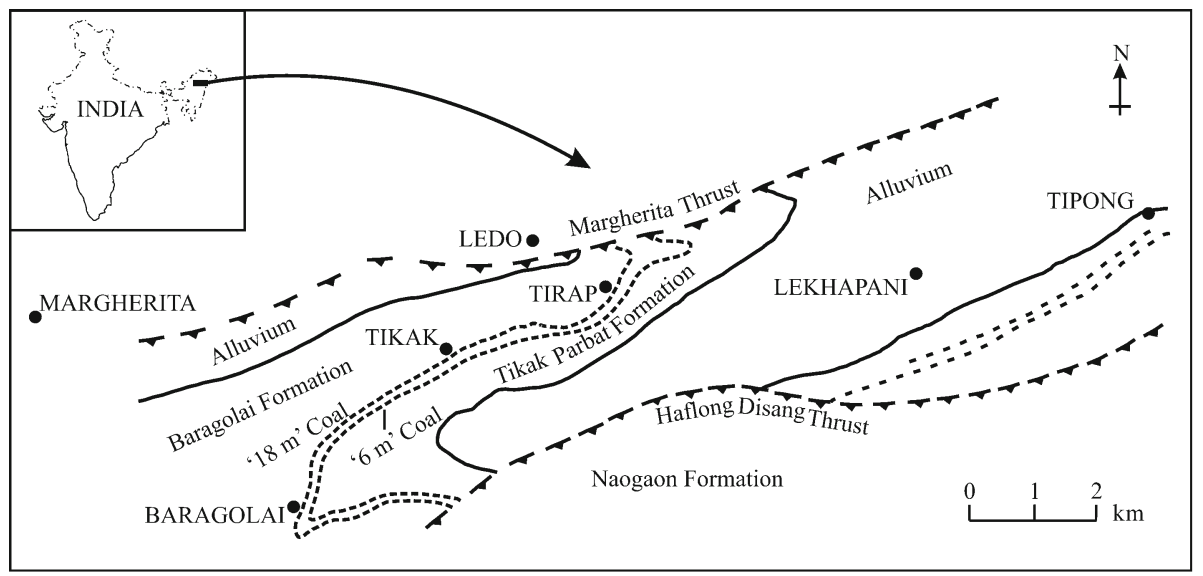

Figure 2. Simplified geological map of Makum Coalfield, Assam (after Ahmed 1996).

latitudes $27^{\circ} 15^{\prime}-27^{\circ} 25^{\prime} \mathrm{N}$ and longitudes $95^{\circ} 40^{\prime}-$ $95^{\circ} 55^{\prime} \mathrm{E}$ (figure 1 ) and is situated along the outermost flank of the Patkai range. On the southern and south-eastern side of the field are hills, which rise abruptly to heights of 300-500 $\mathrm{m}$ from the alluvial plains of the Buri Dihing and Tirap rivers. These hill ranges are traversed by the Namdang, Ledopani and Tirap rivers, whose courses expose sections of the coalbearing Tikak Parbat Formation. The Makum Coalfield encompasses Baragolai, Ledo, Namdang, Tikak, Tipong, and Tirap collieries (figure 2).

This study is concerned with the Tikak Parbat Formation being considered as Late Oligocene (Chattian 28-23 Myr) in age based on regional geology and an array of biostratigraphic controls
(Raj Rao 1981). The formation has five coal seams confined within the basal $200 \mathrm{~m}$ section (Misra 1992).

- Seam no. 5

(2.4 m thick) $\quad 1.3-2.5 \mathrm{~m}$ abandoned

Parting $30-40 \mathrm{~m}$

- Seam no. 4

(1.5 m thick) $\quad 1.2-1.8 \mathrm{~m}$, often merges with

Parting seam no. 3 abandoned $3-18 \mathrm{~m}$

- Seam no. 3

(6 m thick) $\quad 2-7.5 \mathrm{~m}$ worked out in composite seam 2 sections

Parting 38-68 m 
- Seam no. 2

(2.1 m thick)

Parting

$$
1.5-2.6 \mathrm{~m}
$$$$
5-20 \mathrm{~m}
$$

- Seam no. 1

(18 $\mathrm{m}$ thick $)$

composite seam

10-20.8 m, worked

out in 2 or 3 sections

Of the five seams only seam nos. 1 and 3 have been exploited throughout the field.

The Tikak Parbat Formation comprises alternations of sandstone, siltstone, mudstone, shale, carbonaceous shale, clay and coal seams (Misra 1992). However, the occurrence of plant remains is mainly confined to the grey carbonaceous and sandy shales.

The Tikak Parbat Formation is underlain by $300 \mathrm{~m}$ of predominantly massive, micaceous or ferruginous sandstones that comprise the Baragolai Formation, which in turn is underlain by 1100 $1700 \mathrm{~m}$ of thin-bedded fine-grained quartzitic sandstones with thin shale and sandy shale partings that make up the Naogaon Formation (Mishra and Ghosh 1996). Together the three formations comprise the Barail Group (figure 2).

\section{Methodology}

Material for the present study was collected from the sediments of the Tikak Parbat Formation of Tinsukia District, Assam. The specimens were first cleared with the help of a fine chisel and hammer and then photographed in natural low angled light using 10 megapixel digital camera (Canon SX110 and Fuji color 9500). The classification proposed by Read and Hickey (1972) has been followed in assigning the fossil leaves.

Read and Hickey (1972) have proposed five basic features of extant palm leaves that can be used alone, or in various combinations to distinguish fossil palm leaves:

- Leaf blade and segments plicate (not always apparent in fossil fragments of individual segments).

- Leaf blades pinnately veined and either simple or pinnately compound in form, or palmately veined and palmatifid in form.

- Leaf segments with a firm, consistent mid-vein bounded on either side by two orders of parallel veins.

- A ligule-like structure (hastula) at the apex of the petiole (commonly on the adaxial surface, rarely on both surfaces) where the radiating segments are inserted on the palmate blade.

- A well organized primary costa (the attenuated continuation of the petiole into the blade of costapalmate and simple blades).
The affinities of the fossils were traced at the Central National Herbarium, Howrah and the Forest Research Institute, Dehradun after comparing them with the herbarium sheets of the extant plants. One of our specimens (sp. no. BSIP 39910) was destroyed during the extraction. The type and figured specimens are housed in the museum of the Birbal Sahni Institute of Palaeobotany, Lucknow.

\section{Systematic description}

Family: Arecaceae Schultz Sch. 1832

Fossil specimen cf. Iguanura wallichiana
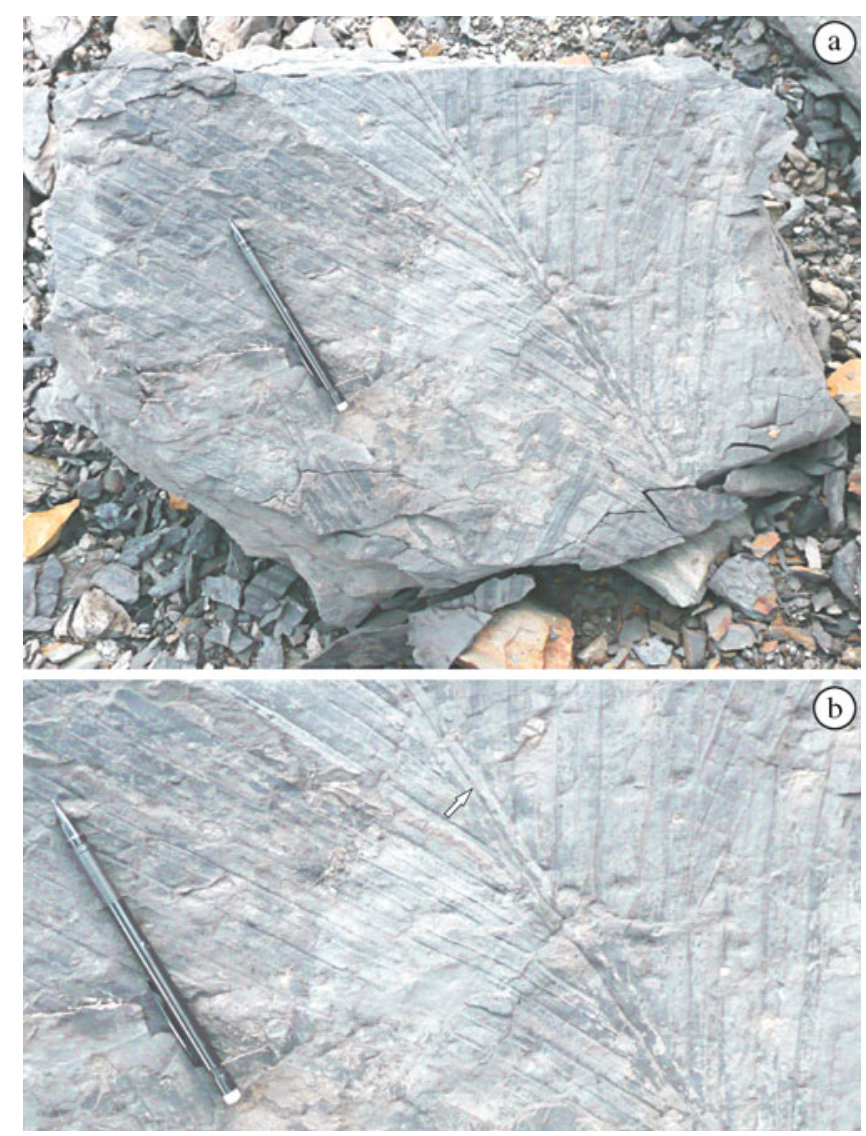

Figure 3. Fossil specimen cf. Iguanura wallichiana (a) A fossil leaf showing shape, size and fused leaflets and (b) a portion of the fossil leaf showing rachis (white arrow) and fused leaflets (pencil size $=15 \mathrm{~cm}$ ).

Description: Leaf large, pinnate; coriaceous in texture; preserved lamina length and width about 42.3 and $50 \mathrm{~cm}$ respectively; apex and base not preserved; rachis strong, about $1.2 \mathrm{~cm}$ thick; preserved leaflets 14, fused adjacently and attached to the rachis by the entire base, about $2 \mathrm{~cm}$ wide on an average, reaching about $40 \mathrm{~cm}$ in length, each with a firm midrib arching away from the rachis, angle of divergence narrow acute $\left(25^{\circ}-41^{\circ}\right)$, numerous secondaries present on either side of the midrib and 
running parallel to it; spines absent on the exposed surface and rachis.

Figured specimen: Specimen no. BSIP 39910

Horizon: Tikak Parbat Formation

Locality: Tirap Colliery, Tinsukia District, Assam, India

Age: Late Oligocene (Chattian 28-23 Myr)

Number of specimens studied: One well preserved specimen

Affinities: The characteristic features of the fossil are: large coriaceous leaf with fused segments, joining strong rachis by their entire bases and parallel venation. All these features indicate that the fossil represents a part of the palm leaf. A large number of palm taxa were observed at the Central National Herbarium, Howrah and the Forest Research Institute, Dehradun. After making comparisons with them it is concluded that it is nearer to Iguanura wallichiana (Mart.) Becc. (Herbarium sheet no. CNH 492342), but as Read and Hickey (1972) have pointed out that it is difficult to identify specimens of modern palms accurately from their leaves alone, no attempt has been made to assign the present fossil palm under the modern genus. The fossil was compared with other similar forms described under various names. Lakhanpal (1964) described a palm leaf from the Tura Sandstone Formation of West Darangiri Coalfield in Garo Hills as Phoenicites with its possible affinities with Phoenix. It cannot be compared with the present fossil due to lack of sufficient details. Bose and Shah (1964) also reported a pinnate leaf as ?Sabalites sp. from the early Tertiary of Laitryngew in Meghalaya, while Mahabale and Rao (1973) recorded a pinnate palm leaf from the Rajahmundry Sandstone of Bommuru. In both the cases leaves are seemingly of the unsegmented pinnate type, but their total lack of description has made it difficult to compare them with the present fossil. Zalaccites jaintiensis described by Barman and Duara (1970) from the Cherra Sandstone of Jaintia Series, Assam differs in the angle of divergence of leaflets or segments which is comparativley more acute $\left(30^{\circ}\right)$ than that in the present fossil. Guleria and Mehrotra (1998) also described a palm leaf, Phoenicites lakhanpallii, from the Deccan Intertrappean beds of Seoni District, Madhya Pradesh. It is different from the present fossil in having only 11 fused leaflets with an angle of divergence $>41^{\circ}$. Sclerosperma safiannikoffii described by Lakhanpal (1966) from the Cenozoic sediments of Congo is very similar in nearly all the morphological features, but the specimen was not complete and his study is also based on cuticular structure which is not present in the present fossil. Under the circumstances, it is difficult to place the present fossil into Lakhanpal's (1966) genus. Sabalites longirhachis described by Kvaček and Herman (2004) from the Cretaceous of Lower Austria is also very similar to the present fossil, but the presence of costa makes the difference from the present fossil. Under these circumstances, the present fossil is being described as fossil specimen cf. Iguanura wallichiana.

The genus Iguanura Bl. consists of eight species distributed in western Malaysia (Mabberley 1997). Iguanura wallichiana with which the present fossil shows some resemblance is distributed in the Malaysian rainforest.

\section{Genus: Palmacites Brongniart 1828 \\ Species: Palmacites makumensis, Srivastava, Mehrotra and Bauer, sp. nov.}
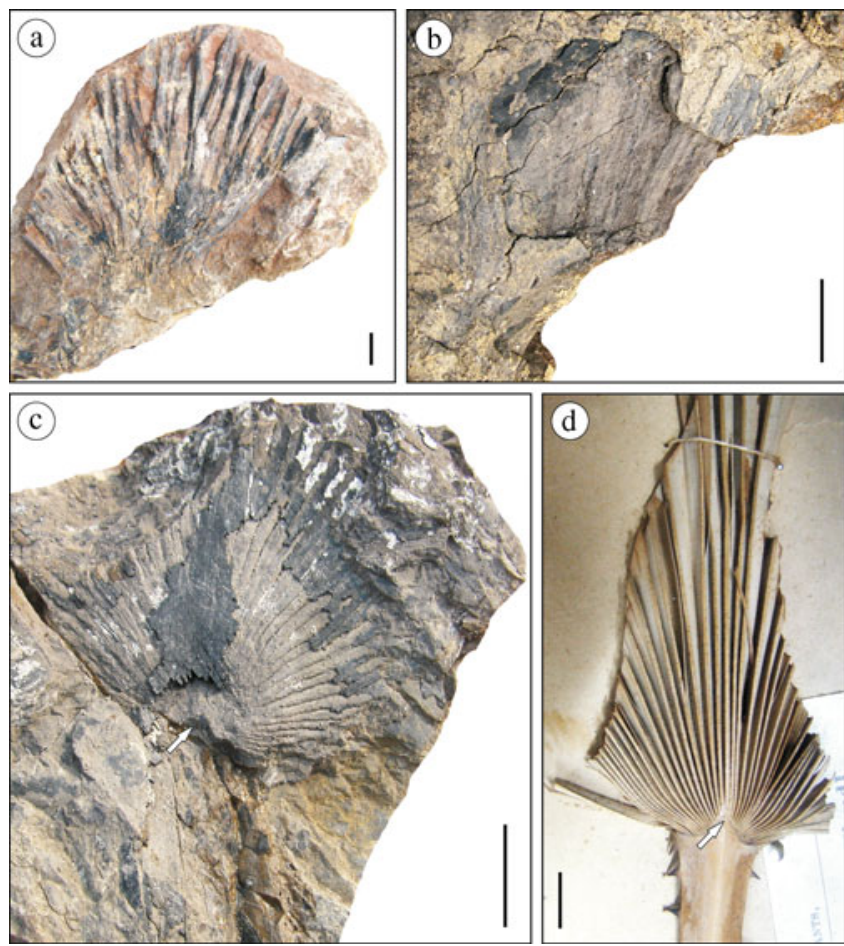

Figure 4. Palmacites makumensis sp. nov. (a, b, c) Fossil leaves showing shape, size and plicate segments (white arrow indicating hastula). (d) A modern palm leaf showing similar plicate segments and hastula (white arrow) (bar scale $=$ $1 \mathrm{~cm})$.

Description: Leaf simple, palmate, fan shaped; preserved lamina length and width about 3$10.5 \mathrm{~cm}$ and $4.6-11 \mathrm{~cm}$ respectively; texture coriaceous; petiole not preserved; hastula present, about $0.5-0.8 \mathrm{~cm}$ in diameter; lamina consisting of about 20-33 plicate segments, leaflets symmetrical, diverging from the base of lamina, varying $2.5^{-}$ $10.5 \mathrm{~cm}$ in length and $0.3-0.5 \mathrm{~cm}$ in width, showing parallel venation with a distinct midrib.

Holotype: Specimen no. BSIP 39911 
Paratypes: 39912, 39913

Horizon: Tikak Parbat Formation

Locality: Tirap and Baragolai collieries, Tinsukia District, Assam, India

Age: Late Oligocene (Chattian 28-23 Myr)

Number of specimens studied: Three

Affinities: The characteristic features of the fossil, namely large palmate leaf with a hastula, consisting of many leaflets diverging from the base of the lamina, each with a distinct midrib and parallel venation indicate its affinity to the Arecaceae. Read and Hickey (1972), in their revised classification of fossil palm and palm-like leaves, have pointed out that it is difficult to assign them to the modern taxa due to similarities in their external morphological features. According to them, "since it is very difficult to identify specimens of modern palms accurately from their leaves alone, no attempt should be made to place fossil palm fragments in genera of modern palms unless unquestionably identifiable with them". According to the key proposed by them to the genera of fossil palm and palm-like foliage, it is concluded that the present fossil should be kept under the genus Palmacites Brongniart (1828).

As far as the fossil records of Palmacites are concerned, they are known from various Late Cretaceous and Tertiary sediments. About three species of the genus, namely $P$. khariensis Lakhanpal and Guleria (1982), Palmacites sp. Mehrotra and Mandaokar (2000) and P. tsokarensis Paul et al (2007) are known from India. P. khariensis Lakhanpal and Guleria (1982) described from the Miocene of Kachchh shows close similarity with the present fossil in having similar shape and size of leaflets and presence of hastula. Unfortunately, venation details of its leaflets are not preserved which make the comparison with the present species difficult. Palmacites sp. Mehrotra and Mandaokar (2000) known from the Oligocene sediments of Arunachal Pradesh is a small fragmentary leaf consisting of only three plicate segments and therefore is not comparable with the present fossil. P. tsokarensis Paul et al (2007) described from the Middle-Late Eocene sediments of Ladakh differs from the present fossil in the absence of hastula. $P$. eocenica described by Daghlian (1978) from North America is different from the present fossil in having less number of plicate segments in lamina and also in the arrangement of leaflets. Under such circumstances, a new species, Palmacites makumensis sp. nov., has been created, the specific epithet indicating the Makum Coalfield where the fossil was collected.

\section{Discussion and conclusion}

Palms are largely distributed and diversified in tropical areas (figure 5) (Uhl and Dransfield 1987) and are much less prominent and diverse in temperate regions (Good 1953; Jones 1995; Gibbons 2003; Lötschert 2006), thus showing very limited frost tolerance (Jones 1995). The low frost tolerance of palms is considered to be an evolutionary conserved trait; i.e., their architecture and more notably a crown composed of large evergreen leaves (Tomlinson 1990) which have limited frost resistance (Woodward 1988) and unique stem physiology prohibiting dormancy (Tomlinson 2006). Palms also exhibit a strong latitudinal diversity gradient (Bjorholm et al 2005) and need water availability for their survival worldwide (Dransfield et al 2008; Punyasena et al 2008). Recent studies in the new world palms indicate that energy, water and absolute latitude are the three main factors influencing species richness (Svenning et al 2008).

In India, palms are reported from Late Cretaceous to Tertiary sediments (Lakhanpal et al 1976; Srivastava 1991; Srivastava and Guleria 2005). They are abundant $(72.9 \%)$ in the Deccan Intertrappean flora considered as Late MaestrichianDanian (Mehrotra 2003) in age (figure 6). The

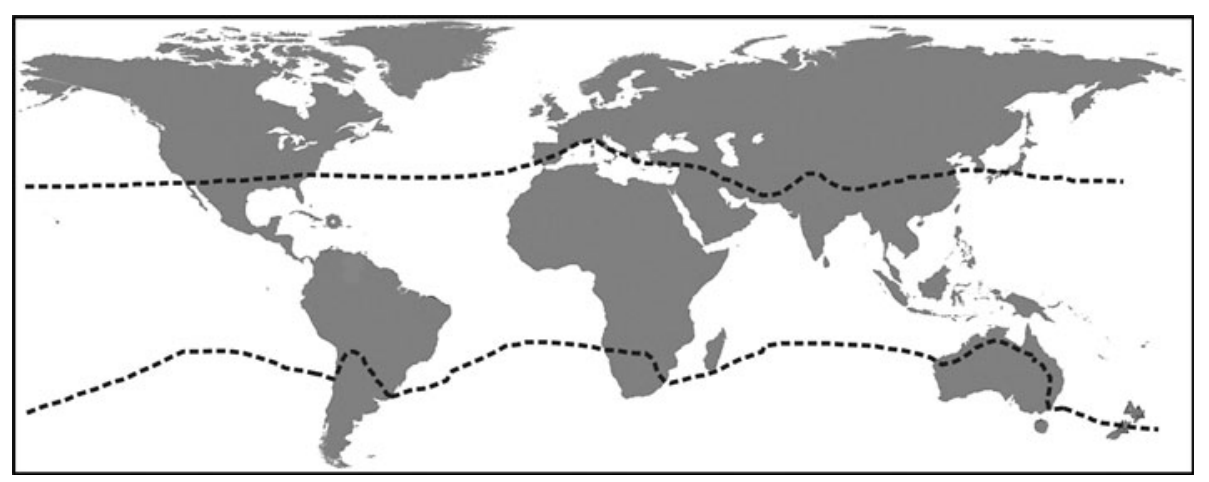

Figure 5. World map in which the broken lines indicate the poleward range margins of natural palm distribution (after Walther et al 2007). 
Late Palaeocene to Late Oligocene palms are known from northeast and northwest India and are uncommon $(10.2 \%)$ compared to the Deccan palms (figure 6). The Neogene palms described from northeast, northwest and south India represent $16.9 \%$ of their floras (figure 6). It can be inferred from the above facts that during the Late Maestrichian-Danian, climatic conditions were more suitable for the growth of palms.

A large number of families are reported from the Makum Coalfield (Awasthi et al 1992; Awasthi and Mehrotra 1995; Mehrotra et al 2009; Srivastava and Mehrotra 2010), of which Annonaceae, Burseraceae, Clusiaceae, Combretaceae, Lecythidaceae, Myristicaceae and Rhizophoraceae are typical pantropical (von Steenis 1962) and their presence in the Makum Coalfield palaeoflora provides evidence that the CMMT (cold month mean temperature) was not less than $18^{\circ} \mathrm{C}$. Similarly, the presence of Fabaceae (Srivastava and Mehrotra 2010) as the most dominant family in the Makum Coalfield and whose abundance and richness covary with temperature (Punyasena et al 2008) also indicates a warm climate. The occurrence of Avicenniaceae and Rhizophoraceae is also very important in terms of the depositional environment. These families are highly indicative of deltaic, mangrove or lacustrine deposition of coal seams and associated sediments in the Makum Coalfield. The presence of palms like Nypa (Mehrotra et al 2003) provides further evidence of a coastal plain environment where both temperature and humidity remained high throughout the year (Tomlinson 1990, p. 20). The warm and humid climate in the Makum Coalfield during the deposition of the palms is not surprising, as the fossil locality was at $10^{\circ}-15^{\circ} \mathrm{N}$ palaeolatitude during the Late Oligocene (Molnar and Stock 2009) and it has been observed that not only the regional, but also the global climate during the Late Oligocene was warm (Zachos et al 2001). A number of fossil palm (macrofossil and microfossil) records are known from eastern Africa during this same period (Pan et al 2006; Vincens et al 2006; Bonnefille 2010) which suggest that palms

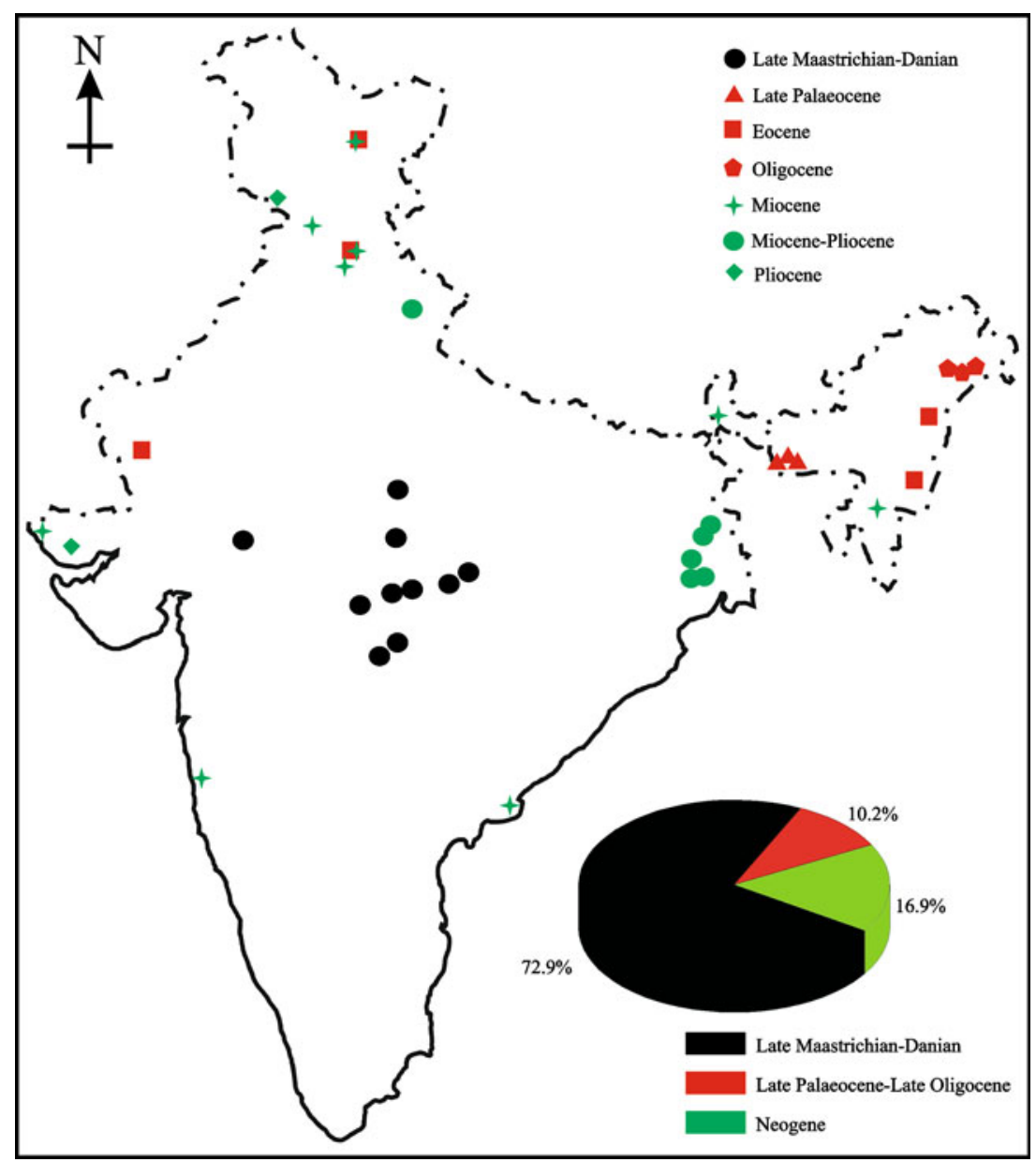

Figure 6. Map of India showing distribution of palm megafossils and a pie diagram showing the diversity of fossil palms in geological time. 
were major elements of forest/woodland floras in Africa and India during this period of time. This is quite interesting, particularly since this is occurring during the advent of Antarctic continental glaciation.

\section{Acknowledgements}

The authors are thankful to the authorities of the Coal India Limited (Northeastern Region), Margherita for permitting them to collect plant fossils from the Makum Coalfield. Thanks are also due to the Directors, Botanical Survey of India, Kolkata and the Forest Research Institute, Dehradun for the permission to consult the herbarium. The authors are also thankful to Dr N C Mehrotra, Director, Birbal Sahni Institute of Palaeobotany, Lucknow for providing necessary facilities an permission to carry out this work. They are also grateful to the anonymous reviewers for their constructive suggestions to improve the manuscript.

\section{References}

Ahmed M 1996 Petrology of Oligocene coal, Makum coalfield, Assam, northeast India; Int. J. Coal Geol. 30 319-325.

Awasthi N and Mehrotra R C 1995 Oligocene flora from Makum Coalfield, Assam, India; Palaeobotanist 44 $157-188$.

Awasthi N, Mehrotra R C and Lakhanpal R N 1992 Occurrence of Podocarpus and Mesua in the Oligocene sediments of Makum Coalfield, Assam, India; Geophytology 22 193-198.

Barman G and Duara B K 1970 Zalaccites jaintiensis gen. et sp. nov. from the Plateau (Cherra) sandstones of the Jaintia Hills, United Khasi and Jaintia Hills District, Assam, India; Sci. Cult. 36(1) 63-64.

Bjorholm S, Svenning J-C, Skov F and Balslev H 2005 Environmental and spatial controls of palm (Arecaceae) species richness across the Americas; Global Ecol. Biogeogr. 14 423-429.

Bonnefille R 2010 Cenozoic vegetation, climate changes and hominid evolution in tropical Africa; Global Planet. Change 72(4) 390-411.

Bose M N and Sah S C D 1964 Fossil plant remains from Laitryngew, Assam; Palaeobotanist 12(3) 220-223.

Bremer K and Janssen T 2005 Gondwanan origin of major monocot groups inferred from dispersal-vicariance analysis; Aliso 22 21-26.

Brongniart A 1828 Prodrome dune histoire des vegetaux fossiles; Dict. Sci. Nat. 57 16-212.

Chase M W, Fay M F, Devey D S, Maurin O, Ronsted N, Davies J and Pillon Y et al 2006 Multigene analyses of monocot relationships: A summary; Aliso 22 63-75.

Couvreur T L P, Forest F and Baker W J 2011 Origin and global diversification patterns of tropical rain forests: Inferences from a complete genus-level phylogeny of palms; BMC Biology 944.

Daghlian C P 1978 Coryphoid palms from the Lower and Middle Eocene of Southeastern North America; Palaeontographica B 166 44-82.
Davis J I, Petersen G, Seberg O, Stevenson D W, Hardy C R, Simmons M P and Michelangeli F A et al 2006 Are mitochondrial genes useful for the analysis of monocot relationships?; Taxon 55 857-870.

Dransfield J, Uhl N W, Asmussen C B, Baker W J, Harley M M and Lewis C E 2005 A new phylogenetic classification of the palm family, Arecaceae; Kew Bulletin 60 559-569.

Dransfield J, Uhl N W, Asmussen C B, Baker W J, Harley M $\mathrm{M}$ and Lewis C E 2008 Genera palmarum: The evolution and classification of palms; Royal Botanic Gardens, Kew, UK.

Gibbons M 2003 A pocket guide to palms; PRC Publishing Ltd., London.

Good R 1953 The geography of the flowering plants; 2nd edn, Longmans, Green and Co., London.

Govaerts R and Dransfield J 2005 World checklist of palms; Royal Botanic Gardens, Kew, UK.

Guleria J S and Mehrotra R C 1998 On some plant remains from Deccan intertrappean localities of Seoni and Mandla districts of Madhya Pradesh, India; Palaeobotanist $\mathbf{4 7}$ 68-87.

Harley M M and Morley R J 1995 Ultrastructural studies of some fossil extant palm pollen, and the reconstruction of the biogeographical history of subtribes Iguanurinae and Calaminae; Rev. Palaeobot. Palynol. 85 153-182.

Henderson A, Galeano G and Bernal R 1995 Field guide to the palms of the Americas; Princeton University Press, Princeton, New Jersey, USA.

Jones D L 1995 Palms throughout the world; Reed Books, Chatswood.

Kvaček Jiří and Herman A B 2004 Monocotyledons from the Early Campanian (Cretaceous) of Grünbach, Lower Austria; Rev. Palaeobot. Palynol. 128 323-353.

Lakhanpal R N 1964 A new record of angiospermic leaf impressions from the Garo Hills, Assam; Curr. Sci. 33(9) 276.

Lakhanpal R N 1966 Some middle Tertiary plant remains from South Kivu, Congo; Musee Royal De L'Afrique Centrale-Tervuren, belgique Annales-Serie in$8^{\circ}$-Sciences Geologiques- $n^{\circ} \mathbf{5 2} 21-30$.

Lakhanpal R N and Guleria J S 1982 Plant remains from the Miocene of Kachchh, western India; Palaeobotanist 30 279-296.

Lakhanpal R N, Maheshwari H K and Awasthi N 1976 A catalogue of Indian fossil plants; Birbal Sahni Institute of Palaeobotany, pp. 1-318.

Lötschert W 2006 Palmen: Botanik, Kultur, Nutzung; Ulmer, Stuttgart.

Mabberley D J 1997 The plant book, a portable dictionary of the vascular plants; Cambridge Univ. Press, Cambridge.

Mahabale T S and Rao S V 1973 Fossil flora of Rajahmundry area; Proc. Symp. Deccan Trap Country INSA Bull. 45 192-214.

Mcneill J 2006 International Code of Botanical Nomenclature (Vienna code); Regnum Vegetabile 146, ARG Ganter Verlag KG.

Mehrotra R C 2003 Status of plant megafossils during the early Paleogene in India; Geol. Soc. Am. Spec. Paper 369 413-423.

Mehrotra R C and Mandaokar B D 2000 Leaf impressions from Oligocene sediments of Manmao, Tirap District, Arunachal Pradesh, India; Palaeobotanist 49 311-315.

Mehrotra R C, Tiwari R P and Mazumder B I 2003 Nypa megafossils from the Tertiary sediments of northeast India; Geobios 36 83-92.

Mehrotra R C, Dilcher D L and Lott T A 2009 Notes on elements of the Oligocene flora from the Makum Coalfield, Assam, India; Palaeobotanist 58 1-9. 
Mishra H K and Ghosh R K 1996 Geology, petrology and utilization of some Tertiary coals of the northeastern region of India; Int. J. Coal Geology 30 65-100.

Misra B K 1992 Tertiary coals of Makum Coalfield, Assam, India: Petrography, genesis and sedimentation; Palaeobotanist 39(3) 309-326.

Molnar P and Stock J M 2009 Slowing of India's convergence with Eurasia since $20 \mathrm{Ma}$ and its implications for Tibetan mantle dynamics; Tectonics $\mathbf{2 8}$ TC3002.

Pan A D, Jacobs B F, Dransfield J and Baker W J 2006 The fossil history of palms (Arecaceae) in Africa and new records from the Late Oligocene (28-27 Mya) of northwestern Ethiopia; Bot. J. Linn. Soc. 151 69-81.

Paul S K, Awatar R, Mehrotra R C, Sharma A, Phartiyal B and Dorjey C P 2007 A new fossil palm leaf from the Hemis Formation of Ladakh, Jammu and Kashmir, India; Curr. Sci. 92(6) 727-729.

Punyasena S W, Eshel G and McElwain J C 2008 The influence of climate on the spatial patterning of neotropical plant families; J. Biogeogr. 35 117-130.

Raja Rao C S 1981 Coalfields of India; Coalfields of northeastern India; Bull. Geol. Surv. India Ser. A $\mathbf{4 5}$ $1-76$.

Read R W and Hickey L J 1972 A revised classification of fossil palm and palm-like leaves; Taxon 21 129-137.

Schultz-Schultzenstein K H 1832 Natürliches System des Pflanzenreichs nach seiner inneren Organisation: nebst einer vergleichenden Darstellung der wichtigsten aller früheren künstlichen und natürlichen Pflanzensysteme; Hirschwald, Berlin.

Srivastava R 1991 A catalogue of fossil plants from India4. Cenozoic (Tertiary) megafossils; Birbal Sahni Institute of Palaeobotany, Lucknow, pp. 1-45.
Srivastava R and Guleria J S 2005 A catalogue of Cenozoic (Tertiary) plant megafossils from India (19892005); Birbal Sahni Institute of Palaeobotany, Lucknow, pp. $1-76$.

Srivastava G and Mehrotra R C 2010 New legume fruits from the Oligocene sediments of Assam; J. Geol. Soc. India 75 $820-828$.

Svenning J-C, Borchsenius F, Bjorholm S and Balslev H 2008 High tropical net diversification drives the New World latitudinal gradient in palm (Arecaceae) species richness; J. Biogeogr. 35 394-406.

Tomlinson P B 1990 The structural biology of palms; Clarendon Press, Oxford.

Tomlinson P B 2006 The uniqueness of palms; Bot. J. Linn. Soc. 151 5-14.

Uhl N W and Dransfield J 1987 Genera palmarum - a classification of palms based on the work of Harold E. Moore, Jr; Allen Press, Lawrence, KS.

Vincens A, Tiercelin Jean-Jacques and Buchet G 2006 New Oligocene-early Miocene microflora from the southwestern Turkana Basin palaeoenvironmental implications in the northern Kenya Rift; Palaeogeogr. Palaeoclimatol. Palaeoecol. 239 470-486.

von Steenis C G G J 1962 The land-bridge theory in botany; Blumea 11(1) 235-372.

Walther G-R, Gritti E S, Berger S, Hickler T, Tang Z and Sykes M T 2007 Palms tracking climate change; Global Ecol. Biogeogr. 16 801-809.

Woodward F I 1988 Climate and plant distribution; Cambridge University Press, Cambridge.

Zachos J, Pagani M, Sloan L, Thomas E and Billups K 2001 Trends, rythms, and aberrations in global climate $65 \mathrm{Ma}$ to present; Science 292 686-693. 